\section{IS DIFFICULTY FEEDING AN INDICATION FOR FRENULOTOMY IN PATIENTS WITH ANKYLOGLOSSIA?}

\author{
A. Patil ${ }^{1}$, D. Liu $^{2}$, T. Ariyanayagam³ \\ M. Mulchandani ${ }^{4}$
}

${ }^{1}$ Barts \& The London School of Medicine and Dentistry, ${ }^{2}$ Imperial College School of Medicine, ${ }^{3}$ UCL Medical School, London, London, ${ }^{4}$ Royal United Hospital, Bath, UK

Background: Ankyloglossia or "tongue-tie" is a common congenital anomaly that can restrict movement of the tongue and thus cause feeding difficulties. The immediate sequalae of this include distress to both mother and baby, and in the long term may result in sub-optimal weight gain. Thus ascertaining the value of frenulotomy in such patients is necessary.

Aims: To analyse the experimental literature relating to frenulotomy in ankyloglossia patients with feeding difficulties.

Methods: PubMed and Cochrane Library search of combinations of MeSH terms: "ankyloglossia", "tongue-tie", "feeding", "frenulotomy", "frenulectomy", "frenotomy", "frenuloplasty", "frenectomy", "tonguetie division" yielded 104 results; 22 relevant and accessible.

Results: Few studies exist to date, and these have concluded in favour of frenulotomy over breastfeeding advice alone. However, the quality of evidence is somewhat questionable. In many cases, the supposed improvement in feeding is subjective, with no data on growth of the baby, which would be a more accurate long-term measure of outcome. Additionally, sample sizes are too small to provide a conclusion of strength. The only randomized control trial to date is hampered by significant bias, as mothers were given the option of frenulotomy if breastfeeding did not improve with counselling.

Conclusion: Issues with diagnosing and assessing the severity of ankyloglossia contribute to the sparsity of evidence available. Additionally, lactation consultants are often in favour of frenulotomy, thus introducing bias into studies. While the evidence is controversial, the minimal adverse effects associated with the procedure lead the author to conclude that it should be offered when feeding difficulties arise.

\section{GALACTOSE-INTERFERENCE ON POCT GLUCOSE ANALYSIS}

J. Christoph ${ }^{1}$, A. Malic ${ }^{2}$, J. Sander ${ }^{3}$, E. Kattner ${ }^{1}$

${ }^{1}$ Kinderkrankenhaus auf der Bult, Hannover, ${ }^{2}$ NOVA Biomedical, Rödermark, ${ }^{3}$ Screening Labor Hannover, Hannover, Germany

Background and aims: Hypoglycemia is a typical, potentially life-threatening symptom in classical galactosemia with blood galactose considerably elevated (up to $\sim 100 \mathrm{mg} / \mathrm{dl}$ ). Therefore we tested the interference of galactose on POCT glucose meters.

Methods: Galactose was added to heparin whole blood (glucose concentration 48-63 mg/dl in series $\mathrm{I}, 0 \mathrm{mg} / \mathrm{dl}$ in series II) to obtain concentrations of 100 and $200 \mathrm{mg} / \mathrm{dl}$ (series I) and 50 and $100 \mathrm{mg} / \mathrm{dl}$ (series II). Due to measurement delays galactose declined in series II to 17 and $52 \mathrm{mg} / \mathrm{dl}$, respectively.

\section{Results:}

\begin{tabular}{|c|c|c|c|}
\hline $\begin{array}{l}\text { I) Glucose } \\
\sim 55 \mathrm{mg} / \mathrm{dl}+\end{array}$ & $\begin{array}{c}\text { Galactose } 0 \\
m g / d l\end{array}$ & Gal $100 \mathrm{mg} / \mathrm{dl}$ & Gal $200 \mathrm{mg} / \mathrm{dl}$ \\
\hline $\begin{array}{l}\text { Glucose } \\
\text { Nova }\end{array}$ & $47 / 55 / 50 / 50$ & $50 / 55 / 51 / 34$ & $44 / 53 / 51 / 48$ \\
\hline $\begin{array}{l}\text { Glucose } \\
\text { Performa }\end{array}$ & 61/63/63/65 & $\begin{array}{l}98 / 103 / \\
93 / 111\end{array}$ & $\begin{array}{l}142 / 144 / \\
147 / 144\end{array}$ \\
\hline $\begin{array}{l}\text { Glucose } \\
\text { ABL835 } \\
\text { No } 1\end{array}$ & 48 & 72 & 95 \\
\hline $\begin{array}{c}\text { II) Glucose } 0 \\
m g / d l+\end{array}$ & $\begin{array}{c}\text { Galactose } 0 \\
m g / d l\end{array}$ & Gal 17,2 mg/dl & Gal $55 \mathrm{mg} / \mathrm{dl}$ \\
\hline $\begin{array}{l}\text { Glucose } \\
\text { Nova }\end{array}$ & $1 / 1 / 1 / 1$ & 0/0/0/0 & 0/0/0/0 \\
\hline $\begin{array}{l}\text { Glucose } \\
\text { Performa }\end{array}$ & 0/0/0/0 & 37/38/37/38 & $53 / 57 / 60 / 57$ \\
\hline $\begin{array}{l}\text { Glucose } \\
\text { ABL835 } \\
\text { No } 1\end{array}$ & 2/2/2/1 & $25 / 25 / 24$ & 45/47/45 \\
\hline $\begin{array}{l}\text { Glucose } \\
\text { ABL835 } \\
\text { No } 2\end{array}$ & $1 / 1$ & $13 / 14$ & $38 / 38$ \\
\hline
\end{tabular}

[Galactose-Interference]

Conclusions: These results show, that most POCT glucose meters are not able to diagnose hypoglycaemia in the presence of galactose.

The FDA has warned physicians of the potential for life-threatening falsely elevated glucose readings in patients who have received ... products containing (or metabolized to) maltose or galactose..., 
and are tested using glucose dehydrogenase pyrroloquinolinequinone (GDH-PQQ)....

Glucose oxidase based systems can as well be influenced.

StatStrip glucose meter (Nova) compensate for interference effects.

\section{2}

\section{DO WE MANAGE TO FEED THE PAEDIATRIC CARDIAC PATIENT ENTERAL AFTER OPEN HEART SURGERY?}

\section{A.-C. Lussagnet \\ Childrens Hospital in Lund, Skane University Hospital, Lund, Sweden}

Aim: PICU in Lund are using a feeding protocol with guidelines for enteral feeding. The Schofield equation for weight to predict the basal metabolic rate is used for calorie prediction. The aim of this study was to examine how the paediatric cardiac patient after open heart surgery is fed enteral at PICU.

Method: Retrospective study including 64 patients between 1 day and 14 years (mean 14 months). Patient's undergone openheartsurgery requiring CPB with a minimum stay at PICU for three days.

Results: Standard is bolus feeding every three hours. Mean ventilator days 3, 3 days. $97 \%$ of the patients had started enteral feeding within 24 h. Predicted calories were reached in 4, 3 days. Differences were seen between groups of age. Age 3-12 months had $70 \%$ reached their goal on postoperative day 3 . Children older than 6 years did not reach the goal before leaving PICU. No significance between time on CPB, cross-clamp time and when the calories were reached. Significance were seen between days on ventilator, patients left with open sternum and reached calories. $67 \%$ of the patients had bowel movements or stool day 2. TPN were started on $3 \%$ of the children. Reasons for not reaching the goal faster were time of fasting. The most common reason for fasting was extubation.

Conclusion: The results shows that enteral feeding is started fast and the goals are possible to reach in the first five days. Problems are seen in the older children.

\section{VITAMIN D DEFICIENCY AND HYPOCALCAEMIC CARDIOMYOPATHY}

\author{
C. Hensey ${ }^{1}$, O. Kozdoba ${ }^{1}$, M. White ${ }^{1}$, K. Walsh ${ }^{2}$, \\ D. Cody ${ }^{1}$ \\ ${ }^{1}$ Diabetes and Endocrinology, ${ }^{2}$ Cardiology, Our \\ Lady's Children's Hospital, Dublin, Ireland
}

Aims: The aims of this study were to document the incidence of hypocalcaemic cardiomyopathy and to highlight its association with vitamin $\mathrm{D}$ deficiency.

Methods: A retrospective chart review was performed of all infants presenting to our Cardiology service with hypocalcaemic cardiomyopathy. Laboratory profiles were documented for each infant, specifically serum calcium, alkaline phosphatase, parathyroid hormone (PTH) and $250 \mathrm{H}$-Vitamin D. Maternal blood results and the method of infant feeding were also documented.

Results: Two male infants presented between January 2009 and March 2010, aged 24 days and 3 months respectively. Both were exclusively breastfed, and were of African origin. Intubation, ventilation and inotropic support was required for each baby. Echocardiography confirmed dilated cardiomyopathy. Blood results were consistent with vitamin D deficiency; calcium $1.23 \mathrm{mmol} / \mathrm{l}$ and $1.28 \mathrm{mmol} / \mathrm{l}$, alkaline phosphatase $988 \mathrm{U} / \mathrm{l}$ and 1487U/L, PTH 150.6ng/l and 392ng/l and $250 \mathrm{H}-$ vitamin D $12 \mathrm{nmol} / \mathrm{l}$ and $10.4 \mathrm{nmol} / \mathrm{l}$. The mothers were both confirmed as being vitamin $\mathrm{D}$ deficient.

Conclusions: Hypocalcaemia is a recognised cause of dilated cardiomyopathy. Vitamin D-deficient rickets is re-emerging as a clinical entity in Ireland. The Food Safety Authority of Ireland recommends that all exclusively breastfed infants, particularly those who are dark-skinned, receive 200 IU of vitamin $D$ from birth to 12 months of age. This is not universally implemented. To date there are no further recommendations to assess or improve vitamin D status in population subgroups, such as pregnant women. Health professionals and parents should be made aware that vitamin $D$ deficiency is prevalent in Ireland, particularly among darkskinned infants. 